\title{
РЕАЛІЗАЦІЯ ОСОБИСТІСНО ОРІЕНТОВАНОГО ПІДХОДУ ЧЕРЕЗ ВИКОРИСТАННЯ ГЕЙМІФІКАЦІЇ В НАВЧАННІ ІНОЗЕМНОЇ МОВИ
}

Стаття уособлює собою спробу осмислення тісного взаємозв'язку та виявлення переваг сукупності гейміфікації в навчанні та особистісно орієнтованого підходу в освіті. 3 огляду на те, щяо головною метою освіти є розвиток особистості, сучасна гуманістична парадигма особистісно орієнтованої освіти спрямована на підтримку й розвиток особистості, на розвиток механізмів самореалізації, саморозвитку, адаптаиії, самовиховання. Серед переваг особистісно орієнтованого навчання перебуває розвиток особистості студента за допомогою навчання, пошук нових методів, форм і засобів навчання. Завдяки доступності інформаційних технологій сьогодні існує можливість їх використання в різних формах освітньої діяльності разом із традииійними методиками викладання дисииплін, які потребують внесення певних нестандартних методичних прийомів. Проблема безперервної освіти є особливо актуальною нині. Особистісно орієнтований підхід спрямовано на те, щчоб підготувати студентів самостійно отримувати знання та розвиватися самим упродовж усього життя, чому також значною мірою сприяють навчальні ігри. Сучасні студенти живуть в особливому інтерактивно-гральному просторі, тому важливо створити комфортне середовище для студентів, щзо дозволяє здійснити гейміфікація. Залучення елементів гейміфікації в освітній прочес дозволяє більшою мірою залучати в нього студентів, підвищує ефективність методу навчання в співпраці. Цей метод покликаний посилити пращездатність студентів, підвищити їхній інтерес до саморозвитку, розвивати творчий потениіал студентів за допомогою інтеграції знань, а також навчити їх груповій діяльності за рахунок спільної роботи. Застосування особистісно орієнтованого підходу разом з елементами гейміфікації в процесі вивчення іноземної мови дозволяє суттєво підвищити мотивацію за рахунок сюжету, дизайну та інтерактивності освітніх ігор й активного залучення студентів у процес живої комунікації; інтенсифікувати освітній процес під час проведення аудиторних занять $і$ в умовах самостійної роботи студентів; розвивати самостійністьстудентів.

Ключові слова: особистісно орієнтований підхід, гейміфікація, активні методи навчання, ігрові методи.

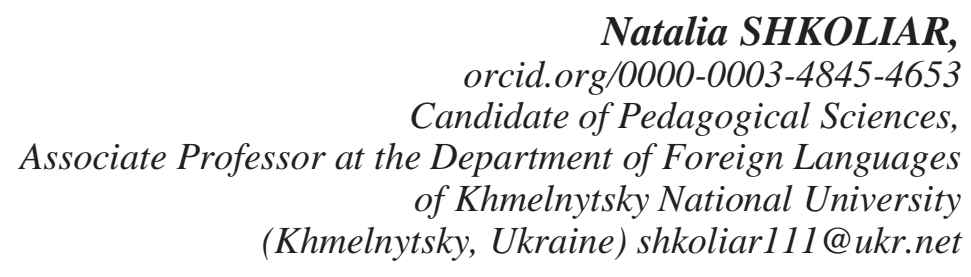

\section{REALIZATION OS PERSONALITY ORIENTED APPROACH THROUGH THE USE OF GAMIFICATION IN FOREIGN LANGUAGE TEACHING}

The article is devoted to interpretation of close interrelation and advantages of combination of gamification in a learning process and personality oriented approach in education. Since the main objective of education is the development of a personality, modern humanistic paradigm of personality oriented education aims at support and development of a personality, at the development of the mechanisms of self-realization, self-development, adaptation, self-discipline. Among the advantages of personality oriented learning there is the development of the personality of a student by means of learning, search for new teaching methods, forms and aids. Owing to accessibility of information technologies, nowadays, they can be used in different forms of educational activities together with traditional techniques of teaching disciplines demanding some unconventional teaching techniques. Today, the problem of lifelong learning is topical. Personality oriented approach aims at preparing students for acquiring knowledge independently and for self-development during all their lives, which is furthered by learning games. Gamification can greatly contribute to creating a comfortable environment for students, which is important, since nowadays, students live in a special interactive gaming environment. The elements of gamification in an educational process are conducive to getting students involved in it, and are able to enhance the effectiveness of cooperative learning method. This technique can improve students' capacity for work, raise their interest in self-development, develop students' creative potential through knowledge integration as well as teach them how to work in cooperation. Personality oriented approach together with elements of gamification applied in the process of learning a foreign language can contribute to increasing motivation thanks to a plot, design and interactive nature of learning games and active involvement of students in live communication; intensify the edu p students'independence.

words: personality oriented approach, gamification, active teaching methods, game based methods. 
Постановка проблеми. Нині підвищення ефективності освітнього процесу, розвиток пізнавальної творчої діяльності студентів через упровадження інноваційних, активних форм і методів навчання, передових педагогічних технологій перебувають серед головних напрямів реформування системи освіти.

Інтенсивний процес розвитку сучасного суспільства активує зміну статусу іноземної мови в системі вищої професійної освіти, що спонукає не лише до зміни методів навчання (від текстуальноперекладних до комунікативно-діяльнісних). Нині головним завданням $\epsilon$ не просто засвоїти певну інформацію, але використати іï як підгрунтя для подальшого самовдосконалення. У зв'язку з цим цілі та зміст навчання іноземних мов у ЗВО орієнтуються на профіль спеціальності й передбачають безперервний пошук шляхів підвищення ефективності освітнього процесу.

Використання лише традиційних форм і методів навчання не може ефективно вирішити проблему підготовки висококваліфікованих кадрів у сучасних умовах модернізації професійної освіти, iï змістового та структурного оновлення. Під час використання цих методів у активному стані знаходиться лише викладач, слухачі ж пасивно сприймають інформацію, тобто процес має інтелектуально пасивний характер (Коваленко, 2009). Традиційні форми й методи навчання можуть забезпечувати передачу знань, але вони не завжди $\epsilon$ ефективними для формування професійних умінь і навичок у майбутніх фахівців. Застосування активних методів навчання веде до активізації пізнавальної діяльності студентів, підвищення мотивації та емоційності навчання, формує професійну компетентність (Мілерян, 2006).

Застосування методів активного навчання, на думку О. Вербицького (Вербицкий, 1991), забезпечує не лише передачу знань, але й створює дидактичні та психологічні умови осмислення навчання, включення в нього студентів на рівні інтелектуальної, особистісної та соціальної активності. Застосування активних методів у навчанні вимагає участі в засвоєнні знань, умінь, навичок усіх психічних процесів, таких як мовлення, пам'ять, уява, мислення, емоції, мотивація тощо. Якщо матеріал, що вивчається, емоційно переживається студентом, то його запам'ятовування відбувається мимовільно, без заучування. У зв'язку з цим особливої актуальності набуває використання особистісно орієнтованого підходу в навчанні студентів ЗВО як цілісного процесу становлення їхньої індивідуальності, життєвого самовизначення, розвитку талантів, розумових здібностей, готовності то подальшого саморозвитку в професійній сфері.

Аналіз досліджень. Особистісно орієнтований підхід, представлений у дослідженнях Н. О. Алексєєва, Г. О. Балла, Д. А. Бєлухина, І. Д. Беха, Є. В. Бондаревської, Г. П. Васяновича, Е. Ф. Зєєра, Л. П. Качалової, С. В. Кульневіча, С. Д. Максименко, О. М. Пехоти, О. Я. Савченко, В. В. Сєрікова, І. С. Якиманської, С. Л. Яценко, які розробляють особистісно орієнтовану модель освіти на основі досвіду вітчизняної та зарубіжної педагогіки та психології. Основним положенням для сучасної вітчизняної педагогіки та психології $\epsilon$ те, що головною метою освіти $\epsilon$ розвиток особистості. Сучасна гуманістична парадигма особистісно орієнтованої освіти спрямована на підтримку й розвиток людини в людині, на розвиток механізмів самореалізації, саморозвитку, адаптації, самовиховання, необхідних для становлення самобутньої особистості, яка здатна взаємодіяти 3 людьми, природою, культурою, цивілізацією (Дубасенюк, 2012: 42).

Впродовж тривалого часу науковцями, педагогами, психологами розглядаються можливості впровадження нетрадиційних методів навчання 3 метою відповідності вимогам сучасної освіти та покращення рівня підготовки майбутніх фахівців. Використанню активних методів навчання для підготовки фахівців різних спеціальностей 3 метою більш якісного засвоєння теоретичних знань і грунтовного відпрацювання набутих умінь присвячено велику кількість досліджень, що свідчить про усвідомлення важливості застосування елементів гри та іiі різновидів для підготовки майбутніх фахівців. Гейміфікації в освіті присвячено роботи М. Барбера, К. Вербаха, К. Каппа, Е. КаррЧеллмен, Д. Кларка, Е. Клопфера, Н. Кравець, Дж. Лі, О. Ткаченко, Дж. Хаммер, Л. Шелдона.

Метою статті $\epsilon$ аналіз застосування особистісно орієнтованого підходу та його реалізації під час використання гейміфікації в навчанні іноземної мови.

Виклад основного матеріалу. Для сучасного інформаційного суспільства форми й методи, в яких викладач є транслятором інформації, а студенти лише слухають, є малоефективними. Зазначений підхід вимагає від кожної особи, яка навчається, незалежно від іiі здібностей до навчання фіксованого часу на засвоєння знань і не враховує людської індивідуальності. Система процесів отримання й використання знань має спонукати студентів навчатися отримувати необхідну для цілей навчання інформацію.

В існуючих численних трактуваннях комп'ютерногоосвітньогосередовищадослідники 
відзначають його очевидний дидактичний статус. Доступність інформаційних технологій дає можливість викладачам використовувати їх у різних формах освітньої діяльності разом із традиційними методиками викладання дисциплін.

Традиційні методи навчання потребують пожвавлення, внесення певних нестандартних методичних прийомів (Ягупов, 2003: 115). Комп'ютеризація освітнього процесу спонукає до перегляду традиційних форм і методів викладання іноземної мови. Розвитку та вдосконаленню освітнього процесу та підготовці фахівців до професійної діяльності в різних сферах життя сучасного суспільства сприяє використання інноваційних методів (Бурлаков, 2004: 4).

Технологія активного навчання $є$ способом реалізації змісту навчання, в якому студенти беруть активну участь, вони $є$ мотивованими на самостійний пошук рішення комунікативних або проблемних завдань. Усе це відбувається в ході використання сучасних методів і засобів навчання, що оптимізує процес навчання і в результаті забезпечує найбільш ефективне досягнення поставлених цілей (Кузякина, 2015). Серед ознак застосування активних методів навчання $є$ результативність, спрямованість методів на розвиток особистості студентів у процесі навчання, оптимальна організація навчального матеріалу, організація освітнього процесу відповідно до навчальної мети, де більша увага приділяється самостійній роботі студентів 3 навчальним матеріалом. Також до позитивних ознак активних методів навчання можна віднести економічність, проектованість, керованість, візуалізацію тощо (Дяченко-Богун, 2014: 77). Саме тому виникає необхідність запровадження активних методів навчання в процес навчання іноземної мови.

Як відомо, ігри зараховують до активних методів навчання, оскільки освітній процес проходить не лише у формі пасивного слухання чи читання. Гру можна підлаштувати під індивідуальні характеристики, інтереси й потреби студентів, що сприяє самостійному пошуку, кращому запам'ятовуванню вивченого матеріалу, підвищенню мотивації та залученості в освітній процес. За своєю природою гра є ідеальним навчальним середовищем, здатним активізувати розумову діяльність студентів, спонукати до прийняття нестандартних рішень, що сприяє створенню усвідомленого навчального досвіду.

У зв'язку з тим, що рівень оволодіння іноземною мовою значною мірою залежить від самостійних зусиль у цьому напрямі, високої мотивації, навчання іноземної мови вимагає застосування особистісно орієнтованого підходу більшою мірою, ніж будь-який інший навчальний предмет. Безперечна перевага особистісно орієнтова- них технологій навчання перед традиційними полягає в тому, що вони вимагають активності з боку кожного учасника заняття, знімають емоційні та комунікативні бар'єри, сприяють набуттю та формуванню в студентів певних особистісних якостей: зібраності, старанності, ініціативності, креативності, комунікативності тощо (Мазайкіна, 2017: 27).

У контексті особистісно орієнтованого підходу відбувається підготовка, яка орієнтується на особистість, і в межах якої здійснюється пошук шляхів задоволення пізнавальних потреб особистості, розв'язання проблем іiі розвитку й підтримки (Письменна, 2013: 251). Особистісно орієнтований підхід реалізується через: виявлення індивідуальних особливостей майбутнього фахівця, надання йому можливості розвитку в процесі підготовки (де забезпечується розвиток здатності до самоосвіти та саморозвитку, формуються навички отримання нових знань шляхом самостійного пошуку й оцінки інформації, має місце навчання застосуванню отриманих знань на практиці); побудову освітнього процесу на принципі варіативності, тобто вибору змісту, методів і форм освітнього процесу з урахуванням особистісного досвіду майбутніх фахівців; створення умов для самостійної роботи студентів, за яких вони перетворюються на активних учасників процесу пізнання, саморозвитку й самоосвіти.

Метою особистісно орієнтованого підходу $€$ гуманізація освітнього процесу, максимальне розкриття потенційних творчих можливостей студентів. На думку О. Бондаревської, особистісно орієнтована освіта спрямована на збереження індивідуальних особливостей учнів, сприяння їхньому розвитку, виховання в них потреб і здатності до самоосвіти, самовизначення, розуміння особистої відповідальності, сприяння розвитку інтелекту й творчих здібностей, задоволення пізнавальних потреб (Бондаревская, 1997). Особистісно орієнтований підхід спрямований на мотивацію студентів, оскільки в освітньому процесі студент є визначальною фігурою, від якої залежать результати роботи, рівень знань і прагнення навчатись самостійно. В основу методики застосування особистісно орієнтованого підходу покладено метод активізації резервних можливостей особистості та колективу, реалізація якого відбувається за рахунок взаємозв'язку індивідуальних і групових форм роботи, використання різних прийомів навчання, включно 3 ігровими 
3 метою створення сприятливого психологічного клімату (Гришкова, 2000: 53). Ігрові методи, що базуються на смарт-технологіях, сприяють розвитку концепції особистісно орієнтованого навчання, яка лежить в основі базових принципів сучасної методики викладання. Використовуючи комп'ютерні технології, студенти активно залучаються до освітнього процесу через інтеракцію iз зовнішнім світом. Використання сучасних технологій, зокрема комп'ютерів, інтернет-ресурсів, спеціальних навчальних мультимедійних програм, дозволяє підвищувати мотивацію студентів завдяки активному залученню студентів у процес живої комунікації, розвивати самостійність студентів завдяки розвитку навичок знаходити, оцінювати та аналізувати інформацію, інтенсифікувати освітній процес, раціонально його організовувати в межах аудиторних занять та в умовах самостійної роботи студентів.

Особистісно орієнтований підхід характеризується формуванням таких когнітивних навичок і вмінь, як рефлексія, планування, внутрішня мотивація, самооцінювання та самоосвіта, а також взаємне оцінювання та взаємне навчання, навчання в співпраці, уміння будувати міжособистісні стосунки, вміння нести відповідальність тощо. 3 позиції того, кого навчають, на думку I. Зимньої, суть особистісно орієнтованого підходу полягає в організації суб'єкт-суб'єктної взаємодії; гарантуванні безпеки особистісного прояву; формуванні активності учня, його готовності до вирішення проблемних завдань; забезпечення єдності зовнішніх і внутрішніх мотивацій учня; отриманні задоволення від розв'язання навчальних завдань у співпраці з іншими учнями; забезпеченні умов для самооцінювання, саморегуляції та самоактуалізації особистості учня; зміни позиції педагога як передавача та контролера знань на позицію фасилітатора (помічника, чия діяльність спрямована не на передачу знань, а на організацію діяльності учня) (Зимняя, 1997).

На думку В. Сєрікова, єдиним способом реалізації особистісного підходу в навчанні $є$ перетворення навчання на сферу самоствердження особистості (Сериков, 1994). Серед переваг особистісно орієнтованого навчання перебуває розвиток особистості студента за допомогою навчання, пошук нових методів, форм і засобів навчання. Метою навчання є розвиток особистості, іiі самосвідомості, їі самореалізація. Створення атмосфери «свободи навчання», за якої студенти не бояться робити помилки, вільно обговорювати проблеми, взаємодіяти в навчанні один з одним, використання методів, спрямованих на стимулю- вання активності та розвитку студентів, сприяють реалізації зазначеної мети (Дубасенюк, 2012: 45). Для створення атмосфери навчання, що виступає сферою самоствердження особистості, iї розвитку та самореалізації, пропонується використовувати емоційно забарвлені методи, серед яких важливе місце належить ігровим методам, як методам, що

здатні найбільше активізувати освітній процес. Інтенсивний розвиток інформаційно-комунікаційних технологій, активне впровадження Інтернету в процес підготовки майбутніх фахівців сприяють

широкому використанню нової технології для розв'язування навчальних завдань - гейміфікації.

Гейміфікація заповнює ту прогалину в освітньому процесі, яка не може бути компенсована іншими методами (до прикладу, словесними методами, практичними заняттями тощо), суттєво

сприяючи закріпленню та поглибленню знань, отриманих під час бесід, лекцій, семінарів, практичних занять, удосконаленню практичних навичок і вмінь. Сутність гейміфікації полягає в припущенні, що вид взаємодії, яка відбувається під час гри, може бути переведено в освітній контекст 3 метою полегшення навчання та впливу на поведінку студентів (Безымянцева, 2015: 191).

Використання гейміфікації в освітньому процесі припускає появу певних переваг, серед яких слід виділити: більш невимушену атмосферу стосовно невдачі, оскільки студенти можуть спробувати знову; більше задоволення в процесі заняття; навчання стає видимим і фіксованим за допомогою індикаторів прогресу; студенти можуть проявляти внутрішню мотивацію для навчання; студенти часто почуваються більш комфортно в ігровому середовищі (Reiners, 2015: 25).

Проаналізуємо, які саме можливості гейміфікації сприяють реалізації процесу викладання 3 орієнтацією на студента. Використання ігрових методів дозволяє більшою мірою залучати студентів у освітній процес і покращити ефективність навчання. Сучасні студенти живуть в особливому інтерактивно-гральному просторі, тому важливо створити комфортне середовище для студентів, що дозволяє здійснити гейміфікація. Включення елементів гейміфікації в процес вивчення іноземної мови суттєво підвищує мотивацію, що досягається за рахунок сюжету, дизайну та інтерактивності освітніх ігор. На нашу думку, під час проведення такого типу роботи відбувається активізація інтересу майбутніх фахівців до набуття нових знань, умінь та навичок. У зв'язку з обмеженою кількістю академічних годин, виділених для вивчення іноземної мови, для засвоєння мовного матеріалу й підвищення зацікавленості студентів 
у процесі навчання ефективним є застосування ігор індивідуального спрямування - кросвордів, «ланцюжків», ребусів.

Інтерактивне середовище робить студента центральним елементом освітнього процесу, надає йому можливість працювати самостійно, керувати знаннями й будувати контент, спираючись на власні інтереси та потреби. Завдяки запровадженню інформаційно-комунікаційних технологій стає можливою автономна робота 3 урахуванням індивідуальних особливостей студентів, створюється можливість для вдосконалення знань, студенти стимулюються до самостійного пошуку інформації, до дослідницької діяльності. В умовах такого середовища в діяльності викладача зменшується частка та значущість функції безпосереднього інформування та контролю, зростає роль організації та підтримки самостійного пізнання, засвоєння вмінь і досвіду, самоконтролю й самооцінки, формування і розвитку особистісних якостей (De-Marcos, 2017). У діяльності педагога акцент 3 передачі знань переноситься на створення умов для їх самостійного виявлення та відкриття. Актуальним є створення на занятті атмосфери розуміння й відкритості, коли викладач підтримує студента й сприяє йому в засвоєнні нового. Під час застосування ігрової технології на перший план виходять: організація експериментально-пошукової діяльності, консультування окремих студентів, пар чи груп, зосередженість на вирішенні конкретної проблеми, підтримка й супровід самостійної роботи студентів, допомога в здійсненні аналізу та оцінки інформації, що надходить, побудова індивідуальної освітньої траєкторії.

Наведемо приклади застосування елементів гейміфікації для вивчення іноземної мови за професійним спрямуванням, метою якого є розвиток мовленнєвих знань і вмінь, необхідних для спілкування на професійні теми. Сьогодні існує велика кількість відкритих платформ, які можна інтегрувати в освітній процес, вибудовуючи індивідуальну траєкторію шляхом створення на їхній основі інтерактивних ігор, квестів та вікторин. Наприклад, користуючись Proprofs.com (https:// www.proprofs.com/games/word-games/wordscramble/digital-design-components/) та вибравши один із шаблонів, можна створити ряд інтерактивних вправ та ігор для використання на заняттях з іноземної мови за професійним спрямуванням 3 метою засвоєння фахової лексики. Більшість ігор базуються на основі питань множинного вибору (на зразок гри «Who wants to be a millionare?»), мicтять різного роду підказки (інколи неправильні) та рівні на основі вибраної автором сюжетної лінії.
Також застосовуються ігри на зразок гри в слова «Scramble», в якій гравці повинні відповісти на запитання, розташувавши букви в правильному порядку. Основне завдання викладача в цьому випадку - створити чим більший банк питань для того, щоб гра була цікавою та різноманітною.

Ще одним вдалим прикладом використання ігор на заняттях з іноземної мови є прототип відомої американської телевізійної вікторини Jeopardy на основі платформи Jeopardy Labs (http:// jeopardylabs.com). Відповідно до теми заняття готується п'ять категорій питань різного рівня складності, які вводяться за допомогою шаблону. В оригінальній версії вікторини запропоновані учасникам завдання представлені у формі тверджень, а відповіді на них - у формі запитань. За бажанням викладача та відповідно до рівня групи цю умову можна адаптувати. Більш того, на сайті можна знайти десятки тисяч готових ігор на будь-яку тематику - від загально побутової до професійної, які можна модифікувати залежно від потреб та вподобань. Як додатковий стимул студентів можна залучати до самостійного створення гри, що не лише сприяє створенню додаткової емоційної напруги, підвищенню рівня їхньої загальної мотивації, але й сприяє ретельному повторенню та закріпленню навчального матеріалу. 3 метою практичного застосування лексики, що опановується студентами за допомогою ігрових методів, на заняттях студентам пропонуються завдання комунікативного характеру - обговорити проблемні ситуації професійного характеру 3 використанням лексичного матеріалу.

Гейміфікація в процесі вивчення іноземної мови може використовуватися для аудиторної, самостійної та індивідуальної роботи й сприяє розвитку мовленнєвих навичок, більше того, можливість індивідуального добору завдань, креативність здатні підвищити рівень мотивації вивчення іноземної мови в студентів.

Висновки. Результати проведеного нами дослідження дозволяють зробити висновки про те, що застосування особистісно орієнтованого підходу разом з елементами гейміфікації дозволяє оптимізувати освітній процес у таких напрямах:

- підвищення мотивації студентів до вивчення іноземної мови за рахунок активного залучення в процес живої комунікації;

- інтенсифікація освітнього процесу під час проведення аудиторних занять і в умовах самостійної роботи студентів;

- розвиток самостійності студентів завдяки розвитку навичок знаходити, оцінювати та аналізувати інформацію. 
Очевидно, що реалізація особистісно орієнтованого підходу, доповненого гейміфікацією, сприяє розвитку автономності, творчого мислення, вміння планувати й оцінювати, забезпечує готовність до безперервної освіти, тим самим утворюючи перехід від пасивного про- цесу навчання до активного та інтерактивного. Успішна інтеграція гейміфікації сприяє розвитку особистості, яка прагне до максимальної реалізації своїх можливостей, що в підсумку повинно сформувати в учнів стабільний інтерес до нових знань.

\section{СПИСОК ВИКОРИСТАНИХ ДЖЕРЕЛ}

1. Безымянцева В. И. Методика преподавания иностранного языка в школе. Москва : Куб, 2015. 288 с.

2. Бондаревская Е. В. Гуманистическая парадигма личностно-ориентированного образования. Педагогика. 1997. № 4. C. 18-25.

3. Бурлаков М. П. Связь методики обучения лексике иностранного языка с лингвистикой и психологией. Іноземні мови. 2004. № 3. С. 3-5.

4. Вербицкий А. А. Активное обучение в высшей школе. Москва : Высшая школа, 1991. 207 с.

5. Гришкова Р.О. Психологические условия реализации личностно ориентированного обучения иностранному языку студентов нефилологических специальностей высших заведений образования : дисс. ... канд. пед. наук. Киев, 2000. $196 \mathrm{c}$.

6. Дяченко-Богун М. Активні методи навчання у вищому навчальному закладі. Витоки педагогічноїмайстерності.2014.№14.C.74-79.URL:http://nbuv.gov.ua/UJRN/vpm_2014_14_14

7. Зимняя И. А. Педагогическая психология : учеб. пособие для вузов. Ростов на-Дону : Феникс, 1997. 480 с.

8. Коваленко А. Б. Особливості застосування методів активного навчання при підготовці до професійної діяльності. Наука іосвіта: Науково-практичнийжурнал Південного науковогоиентру АПН Украӥни. 2009. №5. С. 77-81.

9. Кузякина Н. А. Особенности обучения иностранной лексике как необходимая составная обучения иностранному языку в военном авиационном вузе. Инновационное развитие профессионального образования. 2015. № 1 (07). C. 74-79.

10. Мілерян В. С. Методичні основи підготовки та проведення навчальних занять умедичних вузах : методичний посібник. Київ : Хрещатик, 2006. 80 с.

11. Особистісно орієнтовані технології навчання іноземних мов / уклад. : І. О. Мазайкіна, Т. І. Ямчинська, Є. В. Громов. Вінниця, 2017. 76 с.

12. Письменна Н. Особистісно-орієнтований підхід у контексті гуманізації навчально-виховного процесу. Проблеми підготовки сучасного вчителя. 2013. №8 8(1). С. 250-254. URL: http://nbuv.gov.ua/UJRN/ppsv_2013_8(1) 42

13. Професійна педагогічна освіта: особистісно орієнтований підхід : монографія / за ред. О. А. Дубасенюк. Житомир : Вид-во ЖДУ ім. І. Франка, 2012. 436 с.

14. Сериков В. В. Личностный подходв образовании: концепция и технологии. Волгоград, 1994.164 с.

15. Ягупов В. В. Педагогіка : навчальний посібник. Київ : Либідь, 2003. 560 с.

16. De-Marcos L., Garcia-Gabot A., Garcia-Lopez E. Towards the Social Gamification of e-Learning: A Practical Experiment. International Journal of Engineering Education. 2017. Vol. 33. Issue 1. P. 66-73.

17. Reiners T. Gamification in Education and Business. New York: Springer International Publishing, 2015. 710 p.

\section{REFERENCES}

1. Bezymyanczeva V.I. Metodika prepodavaniya inostrannogo yazyka v shkole [Methods of foreign language teaching in school]. M.: Kub, 2015. 288 p. [in Russian].

2. Bondarevskaya E. V. Gumanisticheskaya paradigma lichnostno-orientirovannogo obrazovaniya [Humanistic paradigm of personality oriented education]. Pedagogics, 1997. Nr4, pp. 18-25 [in Russian].

3. Burlakov M. P. Svyaz` metodiki obucheniya leksike inostrannogo yazy 'ka s lingvistikoj i psikhologiej [Relationship of foreign language vocabulary teaching methods with linguistics and psychology]. Foreign languages, 2004. Nr3, pp. 3-5 [in Russian].

4. Verbiczkij A. A. Aktivnoe obuchenie v vy`sshej shkole [Active learning in high school]. M.: Vy`sshaya shkola, 1991. 207 p. [in Russian].

5. Grishkova R. O. Psikhologicheskie usloviya realizaczii lichnostno orientirovannogo obucheniya inostrannomu yazy`ku studentov nefilologicheskikh speczial`nostej vy`sshikh zavedenij obrazovaniya [Psychological conditions of realization of personality oriented foreign language teaching students of nonphylological specialities of higher education institutions]: (Candidate's thesis). K., 2000.196 p. [in Russian].

6. Diachenko-Bohun M. Aktyvni metody navchannia u vyshchomu navchalnomu zakladi [Active teaching methods in higher education institution]. The origins of pedagogical skill, 2014, Nr 14, pp. 74-79 [in Ukrainian].

7. Zimnyaya I. A. Pedagogicheskaya psikhologiya: ucheb. posobie dlya vuzov [Pedagogical psychology: textbook for higher education institutions]. Rostov n/D: Feniks, 1997.480 p. [in Russian].

8. Kovalenko A. B. Osoblyvosti zastosuvannia metodiv aktyvnoho navchannia pry pidhotovtsi do profesiinoi diialnosti [Peculiarities of application of active learning methods in preparation for professional activities]. Science and education, 2009, Nr 5, pp. 77-81[in Ukrainian].

9. Kuzyakina N. A. Osobennosti obucheniya inostrannoj leksike kak neobkhodimaya sostavnaya obucheniya inostrannomu yazy 'ku v voennom aviaczionnom vuze [Peculiarities of foreign language vocabulary teaching as a constituent 
of foreign language teaching in military aviation universities]. Innovation development of professional education, 2015. Nr 1 (07). pp. 74-7 [in Russian].

10. Milerian V. Ye. Metodychni osnovy pidhotovky ta provedennia navchalnykh zaniat u medychnykh vuzakh: metodychnyi posibnyk [Methodological principles of preparation and conducting lessons in medical schools: methodical manual]. K.: Khreshchatyk, 2006. 80 p. [in Ukrainian].

11. Mazaikina I. O., Yamchynska T. I., Hromov Ye. V. Osobystisno oriientovani tekhnolohii navchannia inozemnykh mov [Personality oriented technologies of foreign language teaching]. Vinnytsia: 2017. 76 p. [in Ukrainian].

12. Pysmenna N. Osobystisno-oriientovanyi pidkhid u konteksti humanizatsii navchalno-vykhovnoho protsesu [Personality oriented approach in context of humanization of teaching and educational process]. Problems of modern teacher training. 2013. Nr 8 (1). pp. 250-254. [in Ukrainian].

13. Dubaseniuk O. A. Profesiina pedahohichna osvita: osobystisno oriientovanyi pidkhid: monohrafiia [Professional pedagogical education: personality oriented approach]. Zhytomyr: Vyd-vo ZhDU im. I. Franka, 2012. 436 p. [in Ukrainian].

14. Serikov V. V. Lichnostny j podkhod v obrazovanii: konczepcziya i tekhnologii [Personality approach in education: concept and technologies]. Volgograd, 1994. 164 p. [in Russian].

15. YahupovV.V.Pedahohika:navchalnyiposibnyk[Pedagogy:teachingmanual].K.:Lybid, 2003.560p. [inUkrainian].

16. De-Marcos L., Garcia-Gabot A., Garcia-Lopez E. Towards the Social Gamification of e-Learning: A Practical Ex l. 33, Issue $1 /-\mathrm{P} / 66-73$.

Reiners T. Gamification in Education and Business. New York: Springer International Publishing, 2015. 710 p. 